\title{
РАЗРАБОТКА МЕТОДА АНСАМБЛЕВОГО ДОКИНГА ИНГИБИТОРОВ ПРОТЕАЗЫ 3CLPRO SARS-COV-2
}

\author{
А.Д. Фомина ${ }^{1,2}$, Д.И. Осолодкинн, \\ ${ }^{1}$ ФГАНУ «ФНЦИРИП им. М.П. Чумакова РАН» (Институт полиомиелита), \\ 108819, Российская Федерация, город Москва, поселение Московский, \\ посёлок Института полиомиелита, домовладение 8, корпус 1. \\ ${ }^{2}$ Химический факультет МГУ им. М.В. Ломоносова, \\ 119991, Москва, ГСП-1, Ленинские горы, д. 1, стр. 3.
}

DOI: 10.19163/MedChemRussia2021-2021-322

E-mail: fomina_ad@chumakovs.su

Цистеиновая протеаза 3CLpro (Mpro, nsp5) расщепляет полипротеины коронавирусов в 11 сайтах. Она является перспективной мишенью для разработки противовирусных препаратов в условиях продолжающейся пандемии COVID-19, и поэтому о ней доступно большое количество структурной информации: за 2020 год в банк белковых структур PDB было депонировано более 280 структур 3CLpro SARS-CoV-2, из них более 220 в комплексе с ингибиторами или иными лигандами. Нашей целью было максимально полно использовать эту информацию для разработки надёжного метода виртуального скрининга потенциальных ингибиторов 3CLpro SARS-CoV-2.

Метод ансамблевого докинга позволяет учесть конформационную подвижность активного центра фермента путём составления набора наиболее представительных структур белка в качестве мишени для молекулярного докинга. Мы отбирали ансамбль структур зрелых, неокисленных форм фермента на основании значения попарного среднеквадратичного отклонения остатков активного центра больше $1.4 \AA$. Ограничения для докинга подбирали по результатам анализа контактов лигандов с остатками активного центра в кристаллических структурах. Докинг выполняли при помощи программ Flare 4.0.2 (Cresset ${ }^{\circledR}$, Litlington, Cambridgeshire, UK; http://www.cresset-group. com/flare/) и DOCK 6.9. Для валидации результатов виртуального скрининга была собрана аннотированная библиотека из 1049 соединений, для которых ранее была определена активность против SARS-CoV-2 или его 3CLpro, путём ручного поиска в статьях и препринтах. Валидацию проводили с помощью анализа ROC.

B нашей работе было показано преимущество точности ансамблевого докинга над докингом в индивидуальную структуру. Разработанная система виртуального скрининга обеспечивает надежность молекулярного докинга и эффективный поиск ингибиторов протеазы 3CLpro SARS-CoV-2.

Работа выполнялась в рамках Государственного задания ФГАНУ «ФНЦИРИП им. М.П. Чумакова РАН» (Институт полиомиелита)

(тема № AAAA-A20-120081790043-5). 